\title{
Fra den nordslesvigske Hjemmefront i 1848.
}

Folkevæbningen i Agerskov og Stafettjenesten.

\section{Af Jorgen Hatting.}

I Skildringen af de slesvigske Krige er det som i al anden Krigshistorie i første Række de militære Operationer, der er de centrale. Kun lidt faar man i Almindelighed at høre om Befolkningens Holdning selv i de Landsdele, hvor Krigen gaar sin hærgende Gang. Og gik end Fortidens Krige ikke saa stærkt ud over Civilbefolkningen som Nutidens, saa maatte dog ogsaa dengang Indbyggerne $i$ et krigsførende Land bære tunge Byrder og risikere om ikke Liv saa dog Ejendom.

I ganske særlig Grad maatte Befolkningen i Sønderjylland i 1848 føle Krigen som noget, der personligt angik den. Det var om Sønderjylland, der i bogstaveligste Forstand blev kæmpet, det var Sønderjylland, som blev Krigsskueplads, og selve Krigens Oprindelse - som et Oprør mod Landets lovlige Regering - maatte grave Skellet dybere mellem de to Nationaliteter og kræve af den enkelte, at han tog Parti.

P. Lauridsens store Værk „Da Sønderjylland vaagnede“ slutter med en kort Skildring af Begivenhederne i Marts og April 1848 i Nordslesvig. Der skal i det følgende gives en mere indgaaende Fremstilling af den Holdning, som de nordslesvigske Bønder indtog $\mathrm{i}$ disse skæbnesvangre Maaneder, først og fremmest af den nordslesvigske Folkevæbning og af den Stafettjeneste, som i Krigens første Maaned oprettedes for at skaffe den danske Hær de nødvendige Oplysninger om Fjendens Bevægelser.

Selv om der i de første Maaneder af 1848 havde været stigende Uro i Holsten og Sydslesvigs Byer, kom Oprøret dog som en Overraskelse for Danskhedens Ledere. Bedst kan dette ses af, at Professor Chr. Flor, Hjernen i den danske Bevægelse, opholdt sig i København. 
Det blev den Aaret før valgte Stænderdeputerede Hans Andersen Krüger, som nu for første Gang fik Lejlighed til at vise sit Mod og sin Handlekraft. Efter at han den 18. Marts paa det „forenede Stændermøde“ i Rendsborg havde protesteret mod Slesvig-Holstenernes Krav, ilede han nordpaa, og allerede den følgende Dags Aften naaede han Haderslev, hvor han gav "Dannevirke“ et Referat af Mødet. Over Hammelev, hvor han havde en Samtale med Hans Nissen, kom han til Rødding Højskole, hvis Forstander Fr. Helweg han satte ind i Situationen, og med hvem han overlagde, hvad der burde gøres. Mest af alt frygtede man, at Horder af slesvig-holstenske Omstrejfere sydfra skulde drage hærgende op gennem Landet, og for at hindre dette maatte der handles og handles hurtigt. Man kunde ikke vente paa, at den danske Hær rykkede ind i Sønderjylland. Flere Steder opstod spontant Tanken om at skabe en Folkevæbning til Værn mod den truende Fare. I Vonsbæk blev der siraks dannet et lille Korps; men større Betydning fik det Møde paa Rødding Højskole, som Krüger og Helweg omgaaende indkaldte til. Trods det korte Varsel mødte der omtrent 150 Mænd, og her vedtoges enstemmigt en Adresse til Kongen. Den indledes med Ordene:

\section{„Allernaadigste Konge!}

Nordslesvigerne have reist sig!

Blodigt fornærmede og overmodigt udæskede ved et lille dumstristigt Parties alt overbydende Anmasselse, hvis Rænker vi altfor længe have været rolige Vidner til, kunne og bør vi ikke taale, hvad man navnlig i Rendsborg den 18. Marts har tilladt sig imod os. Uden at tage mindste Hensyn til os og uden at høre paa Indsigelser fra en af vore Stænderdeputerede, som var der tilstede, har man sendt en Deputation til Frankfurt for at andrage om vor Indlemmelse i det tydske Forbund, for hvilken vi grue, og har overøst os som Danske med de kaadeste Fornærmelser.

Vi vide, at hine frække Oprørere i deres Ondskab ere af- 
mægtige, og at Deres Majestæt paa det kraftigste vil opretholde vor Sag, men som Folk ere vi krænkede og udæskede vi vare alle hine Smædeord værd, om vi rolig taalte slig $\mathrm{Be}$ handling. Vi bør ikke taale den og vi ville ikke taale den ...."

Adressen slutter med at stille følgende tre Krav:

„1) at der ufortøvet udnævnes en dansk Mand af prøvet paalidelig Sindelag, i hvis Hænder indtil videre den høieste militære og civile Myndighed i Hertugdømmet lægges,

2) at alle de Embedsmænd snarest muligt afskediges, som vedkiende sig statsfiendtlige Anskuelser, og som ligesaa lidet fortiene Deres Majestæts Tillid, som de besidde Folkets,

3) at der sørges for, at Bonden øieblikkelig faaer Vaaben i Hænde, og at Landstormen forsynes med paalidelige Befalingsmænd.

For Deres Majestæt ere vi redebonne til at offre Liv og Gods.

Vort Løsen er: Frihed og Kong Frederik!“

Antagelig allerede før Mødet var Krüger rejst til København for at afgive Beretning om Forholdene, ialt Fald havde han ikke Resolutionen med; den afsendtes til Hovedstaden med Assessor Kiær. ${ }^{1}$ )

Medens Krüger var i København, udviklede Begivenhederne sig i Nordslesvig med rivende Hast. "Dannevirke“ kunde meddele, at „den 27. Marts havde Beboerne af Gram Gods besluttet til fælleds Forsvar at patrullere bevæbnede i alle Godsets Byer, især om Natten, for ved Overfald af mulige omvandrende mistænkelige Personer med forenede Kræfter at modsætte sig samme. Hvis skee kan, ønsker man at sætte sig i Forbindelse med de omliggende Sogne. “2)

De gode Gramboere skulde ikke komme til at vente længe. Den 29. Marts sammenkaldte den gamle Amtmand Fr. Johannsen i Haderslev, som ellers paa Grund af sine udprægede Helstatssynspunkter havde været alt andet end populær blandt

1) Dannevirke 28. Marts.

2) ibid. 31. Marts. 
de danske Nordslesvigere, til Møde for Vesteramtets Sognefogder. "Med grædende Taarer", skriver Sognefoged i Agerskov Thomas Høyer i sin Dagbog, redegjorde han for Forholdene og opfordrede Sognefogderne til at være de danske Tropper behjælpelige i enhver Henseende. Fjendtlige Soldater skulde kun nyde det, som ikke kunde undgaas, men intet af Velvilje. Over for dem burde man ikke bruge Vaaben, men Amtmanden anbefalede, at man væbnede sig sogne- eller herredsvis for at bortjage eventuelle Friskarer og Røverbander. Til Slut mindede han Sognefogderne om den Ed, de havde svoret Kongen. ${ }^{3}$ )

I disse Dage herskede der en ret mismodig Stemning rundt om paa Landet i Nordslesvig. I Byerne spillede Slesvig-Holstenerne de fleste Steder Herrer, og man tvivlede stærkt paa, at den danske Hær kunde naa frem før Oprørsarméen. Fra den danske Hær sendte man Løjtnanterne H. Jenssen-Tusch .og F. Hein til Nordslesvig for at hjælpe Bønderne med at organisere sig og sætte Mod i dem. At dømme efter den Rapport, som Løjtnant Hein den 28. Marts fra Vonsbæk sendte den overstbefalende i Kolding, kunde det nok gøres nødigt. Han skriver:

„Efter Aftale med Lt. Jenssen kjørte jeg til Wonsbæk i Mandags Middag for muligen at kunne indvirke lidt paa Bøndernes Stemning Østen for Hadersleben. Ifølge Pastor Helwegs Raad henvendte jeg mig til Præsten, og han lod de fire Mænd i Sognet af meest Indflydelse kalde for at bestemme en Sammenkomst ikke alene for dette, men ogsaa for de nærmeste Sognes Bønder; efter Sigende vilde omtrent møde 40 med Skydevaaben forsynede, dog Resultatet var -8 ! og omtrent 30 Bønder; jeg søgte at opmundtre dem, især til Troskab og Enighed og begynde at aftale flere under disse Omstændigheder nødvendige Ting, og den Forsagthed, som hviler som en mørk Skygge, syn-

3) Nordslesvigsk Søndagsblad Nr. 61899. 
tes virkelig at forlade dem for et Øjeblik; vi aftalte Skiveskydning idag, Krudt og Blye var kjøbt, Leerne gjorte til Forsvar lige, da paa eengang kommer en Stafet fra Hadersleben med den ulyksalige Efterretning, at Militairet fra Syden ledsaget af Kieler Studenterne indtræffe om Aftenen eller i Morgen til Hadersleben. Pastor Boysen havde selv tait med Amtmanden og formodede efter enkelte Yttringer, at det var temmelig autentisk. Nu var Alt tabt, altsaa tog jeg strax ind til Amtmanden, som erklærede, at efter et for nogle Timer siden ankommet Brev var Oberstlieutenant Krohn med 2. Batt., 2 Eskadroner og Studenterfriskarer igjen gaaet tilbage til Flensborg, hvor Miltairet kunde være indquarteret Natten mellem Mandag og Tirsdag. Tilbagetoget var foranlediget ved et Krigsdampskibs (Geysirs) Forbiseiling. Rygtet gik, at Jægerne skulde have fyret paa det. I Hadersleben er Alt roligt, i Omegnen, hvor jeg er, hersker megen Modløshed, og raabe Alle, var der blot Soldater i Haderslev, saa er jeg temmelig overbeviist om, at endeel Bønder vilde forene sig med det Militaire. Alene er her aldeles intet at gjøre, de ere frygtsomme i høj Grad og flere tydsksindede Præster f. Eks. i Øsbye og Mastrup fraraade dem Selvforsvar, da det kunde skade dem i Fremtiden. Jeg gaaer hemmelig omkring fra Gaard til Gaard og forsøger at gjendrive de tydske Redskabers Fortællinger; i Fjelstrup var jeg, for at Præsten og Sognefogden skulde meddele Bøndene, at Wonsbækkerne øvede dem til en bestemt Tid i Skiveskydning og enhver var velkommen, men de skye den Miils Gang og stole paa Coldingerne, som have lovet deres Hjælp; det latterlige at sende $3^{1 / 2}$ Miil for at hente Hjælp er dem ikke indlysende.

Torsdag Morgen tager jeg formodentlig til Rødding Højskole; der ere de meget flinke og skal have Lyst; Forstanderen og Lærerne assistere betydelig, og troer jeg, her ikke kan skee Andet end det Ubetydelige, som er skeet, dog vilde Militairets Ankomst til Byen have en særdeles heldig Indflydelse. Aanden 
i selve Amtet er Størstedelen god, dog virke de tydske Embedsmænd nedtrykkende paa Bønderne ...."

Utvivlsomt saa den gode Løjtnant Hein for pessimistisk paa Situationen. Hvor en eller flere beslutsomme Mænd tog sig af Sagerne, gik det anderledes end i Vonsbæk og Omegn. Saaledes kunde Gaardmand Mumme Petersen den 29. Marts indberette fra Aastrup, at Sognefogden havde indkaldt til et Møde i Skolen. Sognets Præst, Pastor F. Chr. Hansen, havde foreslaaet Oprettelse af en Sikkerhedsvæbning og Statutter til en saadan var blevet udarbejdede. Man mente, at Kammerherre Krogh paa A astrupgaard, som iøvrigt var kendt som Slesvig-Holstener, havde flere Skydevaaben, man kunde faa, og man besluttede da at bevæbne Bønderne med Bøsser og stille dem under Kommando af Præsten med Degnen som Næstkommanderende. ${ }^{5}$ )

Alligevel kan man sikkert fastslaa, at Stemningen i Haderslev Østeramt var temmelig trykket. De talrige, næsten altid upaalidelige Rygter, bar sikkert deres Del af Skylden herfor.

Paa Vesteregnen var Stemningen mere beslutsom. Allerede den 24. Marts havde "Ribe Stifts Avis“ et Opraab undertegnet af „En Mand af Eders Midte“, som opfordrede til, at man inden „tre Solemærker skulde danne frivillige Korps af alle kraftige Mænd og Karle“. De skulde møde med „selvvalgte Vaaben“ til Forsvar for "den Arv, vi have modtaget fra Fædrene og dog gjerne ville bevare for os og vore Børn". Og den 28. kunde Avisen meddele, at 2000 Bønder i Ribes Omegn stod rede til at forsvare Hjemstavnen. Særlig Ribes Borgere synes at have været virksomme, men ogsaa længere sydpaa, især omkring Rejsby, var der en stærk Modstandsbevægelse.")

Saaledes laa Forholdene, da den danske Hærs Avantgarde den 29. Marts rykkede frem fra Kolding og besatte Haderslev.

4) F. A. I. J. S. la Prot. 17. Hærens Arkiv.

5) ibid.

6) Nordslesvigsk Søndagsblad Nr. 6 1899. Denne Skildring synes at hvile paa mundtlig Tradition og er stærkt udstyret med sagnagtige Træk. 
Fremrykningen skabte Panik blandt Slesvig-Holstenerne, samtidig med at den vakte Begejstring hos den Del af den dansksindede Befolkning, som før havde været ved at tabe Modet.

I de følgende Dage fulgte Hærens Hovedstyrke efter, og saa godt som hele Nordslesvig blev besat.

Et Par Dage efter naaede den kongelige Proklamation Sønderjylland, i hvilken Frederik VII opfordrede til Dannelsen af frivillige Korps. Den er dateret den 30. Marts, og det hedder i den:

„Danner, saavidt det staar til Eder, ved egne Midler frivillige, bevæbnede Corps, der slutte sig til min Hær under den militaire Commando. Mange have gjort et saadant Tilbud; efterfølger deres Exempel. Eders Iver for at uddanne Eder til Fædrelandets Forsvarere skal jeg imødekomme ved saa snart som muligt at sende Eder kyndige Befalingsmænd. Stiller Eder Alle som En under mit, under Fædrelandets Banner. Alles Iver styrke Alles Sammenhold, og, om Gud vil, skal Lovligheden besejre Oprøret og føre Fædrelandet til Fred, Frihed og Fre."

Ved Siden af Troppernes Indmarch betød det meget for Stemningen og især for Samlingen af Bestræbelserne for at bevæbne Befolkningen, at de danske Sønderjyders to dygtigste Førere nu vendte hjem. Ganske vist havde Laurids Skau hele Tiden været i Nordslesvig, men hans Indflydelse synes ikke at have været saa stor, som man kunde have ventet. Først da Frederik VII en Uges Tid senere foretog sit Indtog i Haderslev med Laurids Skau ved sin Side, steg dennes Stjerne i Zenith, og senere kom der en Tid - efter at de tyske Tropper havde besat hele Sønderjylland - da han gennem sin dygtige Ledelse af Efterretningstjenesten skulde gøre den danske Hær store Tjenester. Men her i den første svære Tid var det Chr. Flor og Krüger, som blev Samlingsmærkerne. Samtidig med Hærens Indrykning vendte de tilbage til Nordslesvig.

i) Den dansk-tydske Krig i Aarene 1848-50, udg. af Generalstaben, I, Bilag 11. 
Flor havde opholdt sig i Hovedstaden i de bevægede Dage omkring den 20. Marts, hvor han havde været blandt Talerne paa det store Casinomøde. Men da Efterretningerne om Oprørets Udbrud kom til København, henvendte han sig straks til Tscherning for at faa Bemyndigelse til at rejse tilbage til Nordslesvig for at organisere Bøndernes Modstand. Adskillige Nordslesvigere, som studerede i København, vilde følge ham, og først og fremmest stud. theol. Hans Clemensen Refslund, en Gaardmandssøn fra Gestrup i Agerskov Sogn. Han havde været ivrig Deltager i den skandinaviske Bevægelse og havde været med paa Uppsalatoget i 1843. I 1847 og 1848 havde han skrevet flere — anonyme - Artikler i „Fædrelandet“. Han viste sig snart at være en meget brugbar Mand, beslutsom og begejstret for Danskhedens Sag. Senere blev han Koginspektør i Tønder og døde 1902.

Undervejs til Nordslesvig udstedte Flor en „Proklamation til Slesvigerne". Allerede i de Henvendelser, Regeringen og Kongen havde foretaget til Sønderjyderne, havde man betonet Slesvigs Særstilling, og snarere appelleret til dem som Slesvigere end som Danske. Dette kom endnu stærkere frem i Flors Proklamation, et Vidnesbyrd om, at selv han, der som ingen anden kendte Stemningen, ikke var klar over, hvor afgjort dansk Indstillingen i Nordslesvig var. Muligvis kan det dog tænkes, at han først og fremmest ved sin Henvendelse har villet gøre Indtryk paa de mere vaklende Mellemslesvigere. Betegnende er det, at Proklamationen ikke findes trykt i "Dannevirke“. Koch har antagelig fundet den for særslesvigsk. Flor lover Sønderjyllands Befolkning, at Hertugdømmet vel skal have besluttende Rigsdag sammen med Danmark, men iøvrigt have sin egen Landdag for Slesvigs særlige Anliggender. Saavel til den som til Rigsdagen skal Valgretten være meget folkelig. Desuden skal Slesvig have egen Overret og egen Regering. Flor haaber, at Slesvigerne „vil unde vor ungdomsfriske Konge den Lykke at 
gjøre dem, som kjære Slesvigere, til et frit, selvstændig og lykkeligt Folk." ${ }^{\text {" })}$

I den følgende Tid udvikledes der et nært Samarbejde mellem Flor og især Krüger paa den ene, og Hærens Stabschef Kaptajn Læssøe paa den anden Side. Baade Krüger og Læssøe var unge og initiativrige, Krüger kun 32, Læssøe 36 Aar, og man faar af Rapporterne Indtryk af, at de i usædvanlig Grad forstod at arbejde sammen. Som militær Leder af Folkevæbningen i Nordslesvig ansattes Løjtnant Jenssen-Tusch, der ifølge Brev fra Flor til Tscherning havde gjort sine Sager godt i Rødding og som „saa flink“ ud. ${ }^{{ }^{\prime}}$ ) Jenssen-Tusch indfriede $\mathrm{i}$ høj Grad Forventningerne. I de følgende Dage synes han at have været til Stede overalt i Nordslesvig.

Foruden Flor og Krüger gjorde den danske Stænderdeputerede Møller Staal fra Taarning Mølle en god Indsats. Paa den Generalforsamling, som den slesvigske Forening afholdt i Haderslev den 31. Marts, synes det mere at være ham end Laurids Skau, som prægede Mødet, og han hilstes med en Blanding af Harme og Latter, da han rev den Indkaldelse, han havde faaet fra den provisoriske Regering til at møde til en fælles Stænderforsamling i mange smaa Stykker. ${ }^{10}$ ) Den 1. April bad han Generalkommandoen om Officerer til Oprettelse af frivillige Korps, og han tilføjede: „Min foreløbige Plan med et saadant Korps er, at samme skal beskytte det skjønne og frugtbare Tyrstrup Herred mod fjendtlige Skarers Indtrængen, hvilket et paa Egnen lokaliseret Mandskab vil kunne gjøre mod et forholdsviis stort Antal Fjender, da Terrainet overalt er gjennemskaaret med Diger og Grøfter og tildeels opfyldt med Skove...". ${ }^{11}$ )

Hvorledes Stemningen var i disse første Dage af April, skil-

*) Fyens Stifts Adresse Avis 27. Marts.

\&) F. A. I. J. S. 1a Prot. 17. H. A.

10) Fædrelandet 1. April.

11) F. A. I. J. S. 1a Prot. 17. H. A. 
drer et langt Brev fra I. C. Refslund til Carl Ploug. Heri hedder det:

„Da jeg kom til Aabøl Kro, blev jeg omringet af nogle halvfulde Karle, der havde været i Aabenraa til Session, som dog var gaaet overstyr, da Sessionsherrerne ikke var mødte. Disse Karle, der vare fra Gram, sang Studentens glade Liv og søgte paa flere Maader at haane mig $i$ den Overbevisning, at jeg maatte være Slesvigholstener. $\mathrm{Da}$ jeg sagde, at jeg var Dansk og vilde vedblive at være det, var Forliget. nær blevet alt for godt. I Ørdrup var jeg hos Bekjendte. Min Onkel og jeg gik ud og øvede os $\mathrm{i}$ at skyde med Pistoler. Det var, ligesom disse Knald fremkaldte sorte Masser fra Nabobyerne, thi vi havde kun skudt faa Skud, før alle Mand kom marcherende fra Tislund, Gøtterup, Aabøl, Stenderup o. s. v. En af Hovedmændene kom til min Onkel Dins Outzen i Ørdrup, Bonde, for at faa ham med, da man vilde op til Ridefoged Riedell og Herredsfoged Ahlmann, begge i Toftlund. Min Onkel spurgte mig til Raads. Han frygtede for, at Folkemassen vilde nedbryde disse Herrers Huse. Jeg raadede til at bie, til vi havde holdt Møde i Agerskov og faa at see, hvor stærke vi vare, og dette gik min Onkel hen at tilraade dem ikke at gjøre Voldsomheder. Folk vare nærved ogsaa at skjælde ham for Forræder, da han ikke vilde gaae med. En Flok af c. 150 Bønder begave sig da op til Ridefoged Riedell i Toftlund. De skjældte ham for Forræder og raabte, at man skulde binde ham. En Steen fløj mod Vinduesposten, og han spurgte ængstelig, om de havde skarpt ladt. Da de trængte ind i Huset, løbe Pigerne ud med deres Kister, thi de troede, at Huset vilde blive brændt. Ridefogden forsikrede om sin Uskyldighed, og at han ikke havde forstaaet Indkaldelsesordren til Soldaterne, og at han derfor var reist til Amtmand Johannsen for at faae den forklaret, men han var bleven borte $i$ to Dage. Dog, da han med oprakte Fingre svoer Kong Frederik Huldskab og Troskab for Bønderne, lode de ham fare for denne Aften. Til Herredsfogden sendte den forsamlede 
Mængde en Deputation; da hans Kone er frugtsommelig, vilde man ikke forstyrre hende. Næste Dag bleve begge disse Herrer annammede af Amtmand Sponnecks Drabanter og førte til Ribe. Dog havde Riedell af den gamle Usselryg Johannsen i Haderslev forskaffet sig et Sikkerhedspas. der naturligvis ikke blev respekteret.

Da jeg kom hjem til Gestrup i Agerskov Sogn, blev min Faders Huus til min Faders store ÆEngstelse næsten strax til et Hovedkvarteer. Der. kom flere Mænd fra Nørre Rangstrup og Hvidding Herred for at tale med mig, om hvad der var at gjøre. Mens vi talte om, hvilke Foranstaltninger, der skulde træffes, kom Knudsen fra Forballum med sin Broder Studenten ${ }^{12}$ ) og fortalte, at han ved Flensborg havde talt med en Student af Friskaren, der var forsynet med Riffel og mange skarpe Patroner, og som havde meldt om, at de vilde til Kongeaaen. Efter fælles Beslutning afsendtes Student Knudsen til Kolding for at bede om Geværer og et Par Officerer til at lede Bondevæbningen .... Siden hen paa Eftermiddagen kom der Bud, at hver Mand skulde møde i Agerskov, da Fjenden var i Sognet. De mødte med Høforke, Spyd etc., men der var ingen Banditter komne.

Til næste Dag havde jeg sammenkaldt dette Møde i Agerskov, hvor vi toge de Bestemmelser, som jeg tror, jeg allerede har tilmeldt Dem. Hver Mand skulde være bevæbnet og Stafetter bleve ansatte, og ved Klokkekimen skulde alle møde. Al anden Klokkeringning blev forbudt.

Fortegnelse over, hvormange Bøsser, Spyd etc., hvert Sogn havde, skulde indsendes til mig. Sognefoged Høyer i Agerskov paatog sig at lede Stafetterne i Roost, og dette har [han] gjort med Dygtighed som al hans Vandel indtil denne Dag, da Stafetter ere blevne overflødige, eftersom vi nu have Linien langt sydligere. Da vi havde disse Ting ordnede, meente Bønderne,

12) Knud Lausten Knudsen (1806-66), senere Ejer af Trøjborg, og Jens Lassen Knudsen $(1819-86)$, Fader til Digteren Jakob K. 
at de vilde indsætte Embedsmænd i Ridefoged Riedells og Herredsfoged Ahlmanns Sted. Nogle foresloge mig at overtage Ridefogdens Embede. Jeg meente, at det ei var godt at indsætte provisoriske Regeringer, fordi de varede saa kort, og denne Mening fik Overhaand. Nogle foresloge Sognefoged Th. Høyer i Agerskov til Ridefoged. Indbydelse til Hellevad og Bedsted om at tiltræde vort Forbund bleve udstedte og venlig modtagne.

Saa vidt vare vi komne, da vor kjække Krüger fra Beftoft kom hjem; han er "le chevalier sans peur et sans reproche". Hans store Redelighed og han Mod gjør, at alle slutte sig til ham. Vi holdt i Mandags et bevæbnet Møde i Agerskov, hvor der mødte 3 a 4000 bevæbnede Bønder, som holdt Forsamling $i$ en Toft ved Byen paa en lille Bakke. Krüger takkede dem, fordi de vare komne og beklagede kun, at denne mægtige Forsamling ei kunde være afholdt et Par Dage tidligere; thi da havde man kunnet bortfeiet de tydske Fribander fra Røde Kro; men selv nu vilde den ikke være forgjæves; den vilde vise Fjenden, at Nordslesvigerne kunde komme paa Benene, og naar nogen havde Lyst, kunde man jo marchere mod Tonder. Senere opfordrede Krüger til ikke at drage mod Tønder, da 100 Mand af 13de Bataillon og nogle Frivillige vare i Forveien, og han var vis paa, at 5 Mand i røde Trøier vilde være nok til at tage den, da alle vore slesvigholstenske Stæder i Nordslesvig vare ængstede af de danske Tropper og af Landbefolkningen.

Jeg fremsatte et Forslag til Stafetvagter i Lighed med de tidligere i Agerskov oprettede Stafetter, der kunde bringe Efterretning, naar der var Fare paa Færde og kalde Nordslesvigerne under Vaaben. Jeg foreslog Krüger til at føre Overkommandoen over denne Stafetlinie, der burde gaae tværs igjennem Randen paa det slesvigske Forsvarsforbunds sydligste Grændse. Man modtog Krüger til Chef med Acclamation. I Tirsdags toge vi til Rapsted. Det var Kl. 10 om Aftenen, da Folk vare tilsenge, men Krüger lod dem vide, at de maatte 
erklære sig strax, om de vilde være med i det slesvigske Forsvarsforbund eller ikke, da vi maatte vide, hvor vi kunde opstille vor Stafetvagt. Alle kom op af deres Seng, Præsten med, og erklærede da, at de nok vilde være med. Krüger og nogle Studenter toge derpaa tilbage, medens jeg blev og talte med Folkene og udstedte Proklamationer til Bylderup, Burkal og Tinglef Sogne, om de vilde være med os, da vi saa vilde sætte Stafetvagten paa Haistrupgaard i Tinglef og Burkal. I Onsdags tog jeg til Bylderup, hvor jeg lod Sognefogden sammenkalde Bønderne, der erklærede, at de alletider havde holdt med Kongen, at de aldrig vilde ind $i$ det tyske Forbund og alletider vilde høre til Danmark; men angaaende Væbningen og Deltagelsen i Stafetterne maatte de tale med hver enkelt Mand i Sognet. Jeg tog om Aftenen til Rapsted Kro, hvor Nis Hansen strax efter kom kjørende med en heel Pakke kgl. Proclamationer og reiste næste Morgen tidlig for at gaa til Friserne. I Rapsted Sogn vilde de for faa Dage siden have arresteret en dansk Student Jacobsen fra Quorp, men undlode det dog, da han satte dem Pistolen for Brystet. Mod mig. vare de overordentlig høflige. Torsdag Morgen kom Krüger her til mig med 4re Stafetter og reiste med til Haistrupgaard, hvorfra vi udsende dem. Krüger har opfordret mig til $i$ hans Fraværelse at blive der og føre Kommando over Stafetterne. Jeg vilde hellere reise hjem for at tænke paa at skrive Forslag til Ordningen af vore kommunale Forhold, som jeg kjender bedre end de fleste; men jeg bøier mig aldeles under Krüger, som jeg har den umaadeligste Respekt for og Tillid til, skjønt han er altfor hidsig.

Da i Løverdags det Rygte gik, at Tydskerne endnu laae i Rødekro, udrustede vi os fra Nørre Rangstrup Herred. Jeg og alle mine Fættere, der udgjøre en heel Skok, vare til Hest foruden endel andre c. 50 med c. 100 Mand Fodfolk. Da Fjenden var borte, toge vi ned til Hellevad, hvor Folk tildels havde erklæret sig for os. Præsten, Petersen, kunde ikke rigtig gaa 
ind paa vore krigerske Planer. Jeg maa beskrive dette Krigstog fra Rangstrup Herred. Først rede to Mand fra Tislund Sogn med hjemmegjorte Bajonetter paa deres Bøsser, derpaa to do. fra samme Sogn med to uhyre Spyd, derpaa jeg og mine Fættere med Pistoler og saa Spyd og Bøsser om hverandre. Derpaa kom Fodfolket med en hjemmegjort Dannebrogsfane og med alle mulige Vaaben. Det var bleven Aften, og jeg frygtede Excesser, da Folk havde i Kroer faaet noget i Hovedet. Jeg opfordrede Folk til at gaa hjem, hvad Krüger og hans Broder Dr. phil. Krüger ogsaa gjorde, men Folk fra Tislund Sogn sagde, at de vare komne for at tale med dem i Rapsted. Dette kunde have bragt den ene Egn i Krig med den anden. Vi fik dem dog til at gaae hjem. Da Toget kom forbi Præstegaarden, erklærede de fra Tislund, at vi skulde marchere ind i Gaarden. Jeg bad dem om at undlade dette, men de erklærede, at den, der ikke gik med, var ingen dansk Mand. Jeg og min Fætter og flere andre gik ikke ind i Gaarden, men et Par Ryttere og Fodfolket gik ind og raabte paa Præsten, der kom ud. Der gik et Geværskud, og strax afskød alle deres Geværer, der vare skarpladte, som en Udfordring til Tydskerne. Denne Demonstration vilde jeg nødig skulde være skeet netop i Præstegaarden, men hverken Krüger eller jeg kunde forhindre den.

Beboerne i Tislund og Gøttrup vare rustede, da jeg kom hjem, og havde underskrevet, at de i Farens Stund alle som een Mand vilde være hinanden tro og huld. Der er der mange dygtige Krybskytter, og de holde stadig 480 skarpe Patroner i Beredskab.

Igaar reiste jeg hertil fra Haistrup, hvor Krüger for Øieblikket er med sine Stafetter. Jo længere vi ere komne sydpaa, jo meer dorske og indifferente ere Folkene, og vi ville nu ikke sætte Stafetstationen længere mod Syd, da det vil svække Forsvarsforbundet. Jeg har skrevet en Proklamation til Friserne paa Dansk og Tydsk, som vi snart udsender. Concept heraf er indlagt. Da de 100 Mand af 13de Bataillon vare ind- 
quarterede i Tønder, udbredte sig det Rygte, at Friserne var i Anmarch, hvorfor de barikaderede Byen og holdt Nattevagt synden for Tønder. Dette var aldeles overflødigt, dog blev der sendt en Eskadron Dragoner til Tønder, der iforgaars tilligemed de øvrige danske Soldater trak sig ud af Byen mod øst. Byen er aldeles rolig, men var noget bange for de danske Beboere fra Vestkanten, der i Forening med Ribe Borgerchor i Søndags droge mod Lygum Kloster. Byen havde iforvejen saa godt som overgivet sig til Krüger ad fredelig Vei, men da Folk vare komne paa Benene, vilde de ind i Byen. Pastor Koch fra Skærrebæk, der efter Sigende har ladet sig give sit Embede af Kammerjunker Krogh, er nu ravdansk og anførte Bønderne. Et Par Mænd fra Rapsted, der vare i Kloster den Dag, have fortalt mig, at han truende forlangte, at de skulde erklære, om de vare tydsk eller dansk, hvorpaa de svarede komisk: Wir sind Dänen. Han holdt dem da en Pistol for Brystet og holdt et Fandens Hus med dem, hvorover de beklage sig. Han har tillige indgivet en lang Klage over Herredsfoged Ahlmann fra Toftlund, der er fældet tilstrækkelig i forveien.

Egnen seer ganske krigersk ud. Næsten alle Reisende ere bevæbnede med Pistoler, Sabler, Bøsser o. s. v.

Man trænger haardt til Geværer, Kugler og Krudt, og det er ikke andet end Ret, naar man er misfornøiet over, at Ribe og Kolding strax blev bevæbnede, og ingen sendte Geværer til Nordslesvig, der er eller var meget udsat. I Tønder tog man 170 Geværer, der vare komne fra Rendsborg og sendte dem til Ribe.

Det er galt, at Armeen arresterer saa mange underordnede Personer, Sognefogder o. s. v. Krüger har lovet, at hvis man vedbliver dermed og lader de Store gaa mod Caution, saa skal han nok arrestere dem. Der kunde nok nævnes en enkelt af saadanne.

Iforgaars var der en Dragon Eskadron nede mod Bau at rekognoscere. To fjendtlige Eskadroner flygtede, og Jægerne 
fyrede paa vore uden at træffe dem. Soldater, der drage gennem Landet, spørge Bønderne, om de ikke have en tydsk Præst eller Sognefoged eller saadanne, som de kunne arrestere. Dette er den slette Følge af, at det er Soldater, der foretage Arrestationer.

Her i Aapenraa, hvortil jeg kom igaar, ere to Lager flygtede. Prof. Flor, som jeg har talt med $i$ dette Øieblik, bad mig sige Dem, at et Par danske Candidati medici vist her kunde gøre gode Affairer, da Physikus og Dr. Grauer ere utilstrakkelige.

Jeg har her skrevet løst og fast i størst muligt Hastværk, for at give Dem saa klart et Billede af Landet som muligt. Saa længe Kampen er en Kamp om Slesvigholstenerne, agter jeg ikke selv at tage activ Del i Striden. Bliver det en Kamp mellem Danmark og Tydskland, da maa jeg og hver dansk Mand være med. Gud give, at vore nye Ministre ikke trættes af Vanskelighederne ved deres store og farlige Værk og ikke frygte for at give vore forræderske Embedsmænd tilbage. til Tydskland igjen. Nordslesvigerne skulle staae dem bi og ville ikke taale, at de høiere Embedsmænd, der ere skyldige i Høiforræderi, indsættes igjen. Lev vel!

\section{Deres hengivne}

Frihed, Lighed og Broderskab!“(13)

H. C. Refslund.

Refslunds lange Brev er jo ikke ganske klart, hvad Rækkefølgen af de skildrede Begivenheder angaar. Selve Brevet er paabegyndt i Ravsted den 6. April, men først fuldendt i Aabenraa den 8. Rækkefølgen af de Begivenheder, han skildrer, vil fremgaa af det følgende:

Omkring den 28. Marts kom Refslund til sit Hjem i Gestrup i Agerskov Sogn. Det Møde, paa hvilket han foreslog Oprettelsen af en Stafetvagt, blev afholdt Torsdag den 30. Marts. Krüger har da endnu ikke været til Stede, skønt Mor-

1.) Flougs Papirer. K. B. 
ten Eskesen mener det. $^{14}$ ) Paa dette forberedende Møde vedtoges det at sende en Hyldingskrivelse til Kongen, i hvilken man udtalle Afsky for den oprørske Bevægelse og lovede „vor trofaste Vedhængen ved vore Fædres Land og vor. folkelige Konge“. Forsamlingen takker for Kongens Svar af 24. Marts til den slesvig-holstenske Deputation „og for de deri lovede store Friheder, og navnlig fordi der tilsikres os vor gamle, kære uopløselige Forbindelse med Kongeriget, ligesom vi oprigtigt og alvorligen vidne, at vi alle $i$ Trofasthed og Endrægtighed ville opstaa til Værge for Konge og Land mod alle indvortes og udvortes Fjender og leve og dø, vore Fædre lig, i nedarvet Troskab". ${ }^{15}$ )

Antagelig Fredag den 31. Marts er Krüger da ankommet, tids nok til at han kunde være med i det i Refslunds Brev omtalte Tog til Hellevad. Mandag den 3. April fandt saa det store Bondestævne i Agerskov Sted. Flor havde faaet Bemyndigelse til sammen med Løjtnant Jenssen-Tusch at overtage Kommandoen, men han var selv klar over, at han savnede de nødvendige Forudsætninger for at kunne lede et saadant Foretagende, og at han kunde gøre mere Nytte ved at følge $\mathrm{H}$ ren og med sit omfattende Personalkendskab sørge for, at de oprørske Embedsmænd blev fængslet. Han stillede Forslag til Læssøe om Oprettelsen af en Kommission med sig selv som Formand for at klare dette ømtaalelige Spørgsmaal, hvor man hverken maatte gaa for strengt eller for mildt frem, men Forslaget blev ikke godtaget. ${ }^{16}$ ) I Agerskov maa han hurtigt være blevet klar over, at Krüger allerede havde et fast Greb om Tingene, og at man ikke kunde onske sig en bedre Mand end denne til den ansvarsfulde Post. Det blev da Krüger, som i den første Tid blev Folkevæbningens egentlige Leder - Styr-

14) Morten Eskesen: Hans Krügers Saga S. 61.

15) ibid. S. $62 \mathrm{f}$.

16) F. A. I. J. S. 1a Prot. 17. H. A. 
kerne i den østlige Del af Haderslev Amt synes stadig at være under Ledelse af Møller Staal.

I de endelige Bestemmelser for „det nordslesvigske Forsvarsforbund" blev det - udover hvad Refslund i ovennævnte Brev meddeler - vedtaget, at hvert Sogn, som slutter sig til det, skal opstille en lille Dannebrogsfane paa Kirken, og at hvert Herred skal anskaffe sig en Fane, i hvilken Herredets Vaaben skulde være malet. ${ }^{17}$ )

Det store Problem var, hvorledes man skulde fremskaffe de nødvendige Vaaben. En Del Geværer havde man vel mest formodentlig Jagtbøsser - men ellers maatte man klare sig med Leer og hjemmelavede Lanser, ligesom i de andre Bondevæbninger, som var blevet dannet i Vestslesvig, paa Sundeved og paa Als. Krüger sendte Refslund til Aabenraa, for at han kunde fremskaffe nogle Geværer, der var blevet taget ved Erobringen af Tønder og Aabenraa, men General Hedemann, som han først traf i Kliplev, svarede, at Krüger maatte henvende sig til de lokale militære Myndigheder. ${ }^{18}$ ) Geværerne fra Tønder - 170 ialt — fik Nordslesvigerne i alt Fald ikke; dem havde Ribe Borgerchor, som under den beslutsomme Løjtnant Siemsens Ledelse havde deltaget i Toget mod Tønder og Løgumkloster, lagt Beslag paa. ${ }^{19}$ ) Hvorvidt Krüger senere fik fat paa nogle af Geværerne fra Aabenraa, meldes der intet om.

Man maatte altsaa klare sig med Leerne. I Odense var der blevet dannet en Komité under Ledelse af Borgmester, Justitsraad Chr. Estrup, og denne sendte nu 300 „Stridsleer“ til den nordslesvigske Bondebevæbning. De blev overleveret af Købmand Ørnstrup og af den polske „Officer" Sasse (et enkelt Sted kaldes han "Professor"), "som i den polske Frihedskrig 1830-31 selv har anført Afdelinger af Leemænd, en Bevæbning, der er ligesaa gammel som national i Polen og i hiin Kamp alene expe-

17) ibid.

18) Plougs Papirer. K. B.

19) Fra Ribe Amt IV. 
derede c. 50.000 Russere ud af Verden. Denne polske Herre er fulgt med i den Hensigt at undervise Nogle i Nordslesvig i Stridsleens Haandtering, deels mod Rytteri, dels mod Fodfolk, hvorved den bliver til et af de farligste Vaaben for Fjenden, medens den i Uindviedes Hænder ei nytter stort. Indøvelsen staar kun paa i 4-5 Dage. Der er nu Udsigt til, at hiin for enhver Fjende frygtelige Bevæbningsmaade, der er saa meget lettere at sætte iværk, som enhver Høstlee $i$ en Time kan omdannes til en Stridslee og hele Landet saaledes paa een Dag staae bevæbnet, - kan blive indført hertillands og danne et nyt Jernværn mod Nationens og Rigets Undergang i den mørke Fremtid. Derfor op, I raske unge Karle, og lærer at blive danske Leemænd! ${ }^{(20}$ )

Trods dette bombastiske Opraab i „Dannevirke“ lykkedes det næppe at skabe overvældende Tillid til Stridsleernes Kampværdi. I alt Fald var Krüger stadig ivrig efter at erhverve Skydevaaben til sine Folk, og efter Slaget ved Bov den 9. April fik Refslund Lov til at udtage 50 Geværer af Krigsbyttet, som han med Lorentz Outzen fra Bovlund sendte til Bevtoft.

I Virkeligheden var Folkevæbningens Rolle udspillet efter Slaget ved Bov, selv om den ogsaa i den følgende Tid vedblev at holde Øvelser med Leerne. Men der var efter Slesvig-Holstenernes Nederlag ikke umiddelbart Fare for, at Friskarer skulde oversvømme Nordslesvig. Den 18. April indtraadte Krigstilstanden med Preussen, og vi stod nu over for Tropper af en ganske anden Kvalitet. Over for dem var Folkevæbningerne uden nogen Værdi.

Folkevæbningernes Betydning laa i det hele taget mindre i det militære end i det psykologiske. Ganske særligt gjaldt dette naturligvis Sønderjylland, hvor det kunde være af stor Værdi at have et saa stærkt Bevis paa Befolkningens Danskhedsfølelse som muligt. I den „Instrux for de Officerer, som ere fordelte $\mathbf{i}$

20) Dannevirke 6. April. 
Districterne i den Hensigt at organisere Folkevæbningen", som Tscherning udsendte den 7. April, hedder det betegnende nok $i$ Artikel 1:

„Formaalet med denne Foranstaltning, hvilket ikke bør tabes af Sigte, er mere at berolige den stærke Spænding af krigersk Patriotisme, som er vakt af Tidsomstændighederne, end at forøge den.

Hr. N. N. vilde desaarsag i Forbindelse med Localautoriteterne søge at træffe saadanne Foranstaltninger, som, idet de tjene til at vedligeholde Iveren for den gode Sag, tillige kunne virke til at lede Begejstringen i en rolig Strøm".

I Instruksen fastsættes der endvidere, at Førerne for Korpsene maa være Mænd, som nyder Anseelse lige saa meget fra det borgerlige Standpunkt som med Hensyn til krigersk Dygtighed, at intet Korps kan anerkendes, hvis det ikke bestaar af mindst 50 Mand, at Føreren for et Kommando paa 50-100 Mand skal betragtes som Løjtnant, Føreren for 100-200 Mand som Kaptajn. ${ }^{21}$ )

Mere betydningsfuld end Folkevæbningen var den Stafettjeneste, som var blevet oprettet samtidig med den paa Mødet i Agerskov. Dets Formaal var at „holde Øje med Fjendens Bevægelser for at kalde Nordslesvigerne under Vaaben, naar nogen Fare maatte true". Men desuden skulde den forsyne Hæren med Oplysninger, og det blev paa dette Omraade, den kom til at gøre en Indsats.

Som nævnt blev H. C. Refslund Stafetkommandør, naar Krüger ikke var til Stede, og denne var stadig optaget.

Krügers utrættelige Virksomhed fremgaar af et Brev, han den 6. April sender Tscherning, og i hvilken han skriver: „Jeg har ladet udgaa Proclamationer til Sognene paa Landet, skrevet Breve til Embedsmænd og svaret paa deres Gensvar, gjort personligen mange Reiser omkring paa Landet og sendt Stafetter over Stafetter til Sogne og Byer for at ordne en almindelig

21) Den dansk-tyske Krig i Aarene 1848-50. Bilag 12. 
Væbning og for at opmande Folket til Modstand mod indvortes og udvortes Fjender ....“22)

Refslund blev da den egentlige Leder af Stafetvagten. Under sig havde han fire Stafetter, blandt hvilke var hans Fætre Bunde Refslund fra Bovlund og Kristen Lautrup fra Gestrup, alle "modige Mænd, der tør see Faren under Øine i Nærheden".

Stafetliniens Hovedkvarter blev lagt paa Haistrupgaard $\mathbf{i}$ Bylderup Sogn. To Stafetter skulde Nat og Dag patrouillere mod $\varnothing$ st, to mod Vest. Stafetterne var forpligtede til, saa snart de erfarede noget om Fjendens Bevægelser, da at gøre Meddelelse herom til den nærmeste militære Post og til Stafetkommandoren. Denne sidste lod derpaa Meldingen gaa nordpaa. Her skulde de i Forsvarsforbundet sammensluttede Sogne stille Stafetter, som ikke behøvede at være faste Folk. Planen saa saaledes ud:

„Burkal og Tinglev Sogne enes om at stille en til Jyndevad Mølle, hvor han Dag og Nat holder sig rede til at ride til Bylderup Kro med den Ordre, Stafetkommandøren giver ham.

Bylderup og Uge Sogne stiller ligeledes en, der bringer Ordre til Ravsted Kro.

Bedsted og Hellevad Sogne en til Agerskov Kro.

Agerskov og Branderup Sogne en til Sognefogden i Hyrup.

Bevtoft, Tirslund og Toftlund Sogne en til Gabøl Kro.

Nustrup og Skrydstrup Sogne en til Gramby.

Gram og Østerlinnet Sogne en til Rødding Højskole.

Disse Stafetter maa stadig være rede til at ride af Sted, naar Befaling gives. Saasnart en Stafet er afgaaet, maa Sognefogderne straks stille en ny.

Naar Fjenden nærmer sig, har Byerne efter Opraab at væbne sig og ile det truede Sted til Hjælp".

Denne Plan, som er udarbejdet af Krüger den 5. April, traadte straks i Kraft, dog med den ÆEndring, at da Hovedstationen blev Hajstrupgaard og ikke som forst fastsat Jyndevad Mølle,

${ }^{22}$ ) Krigsministeriets Arkiv I, til Prot. IV, 1848, Løbenr. 31, R. A. 
udgik Stafetterne fra Burkal og Tinglev, Bylderup og Uge, og i Bevtoft blev Stationen Bevtoft Kro ikke Sognefogden i Hyrup. Fra Bevtoft Kro, "Spader Es“, som den kaldtes, ledede nu Krüger hele Organisationen. ${ }^{23}$ )

I de følgende Dage afsendtes regelmæssigt fra Hajstrupgaard Meldinger om Fjendens Bevægelser, men efter Sejren ved Bov skubbede man Stafetvagterne længere mod Syd, og Medelby blev nu Refslunds Hovedkvarter. Meldingerne herfra havde mindre militær Betydning, da Hæren jo stod Syd for Stafetlinien, men til Belysning af Stemningen i Mellemslesvig er Refslunds Rapporter og Breve meget oplysende.

Refslund var alt andet end glad for at opholde sig i Medelby, hvis Beboere efter hans Mening var et "sløvt og usselt Folk“, der havde været „Bureaukratiets hengivne Slaver“. Og det blev ikke bedre, naar han kom længere ned i Mellemslesvig. I Brarup tog han ind til "den bekjendte Hestehandler P. Marcussen", som han kendte i Forvejen som dansksindet. Marcussen blev dog alt andet end begejstret for hans Ankomst. I sin Rapport fra Medelby den 19. April til Læssøe fortæller Refslund videre om Besøget:

„Jeg maatte for Guds Skyld ikke kalde Folkene i Byen sammen og tale til dem; thi de vilde skyde mig eller arrestere mig, og jeg vilde gjøre ham ulykkelig med hans Familie; thi endnu herskede Tydskerne her. I Kroen laa Frisernes Stafet og nogle af de værste Slesvigholsteinere, og hvis disse vidste, at jeg var her, vilde de arrestere mig. For et Par Dage siden havde man i Leck faaet at vide, at jeg med et Par af Stafetterne havde været nede $i$ en By Holt her i Sognet. Det blev da udtalt og givet almindeligt Bifald, at man burde arrestere saadanne Folk for dermed at udløse sine egne Fanger. Der er imidlertid ingen Bevægelse skeet for at bevirke dette, og da vi her ligge 5 Mand velbevæbnet, haaber jeg, at denne Lyst nok vil forgaa Folk saa meget mere, som vi idelig lade dem høre vor Skyden og Exer-

23) Nordslesvigsk Søndagsblad Nr. 6. 1899. 
ceren. P. Marcussen i Braderup paamindede mig indstændigen om ikke at gaa til Niebøl endnu, hvilket jeg da heller ikke har forsøgt; thi for det første kunde jeg ikke komme derhen, og for det andet vilde man ikke lade mig komme tilbage. Alle Veie paa een nær til Marsken ere opkastede, og paa denne ene bliver man anholdt af Vagten og nøie undersøgt. Flere tydske Embedsmænd ere flygtede til Niebøl og ophidse her Friserne ved en Art Terrorisme, idet de give de simpleste Karle Brændeviin etc. og gjøre de danske Slesvigeres Navne forhadte blandt saadanne, der ikke kunne antage Grunde.

Han troede, at der vel kunde komme en Tid, da Besindighed kunde vende tilbage, men endnu vilde det især være galt om de, hvis Navne vare brugte til at ophidse Folk med, vilde tale til Friserne; det kunde han bedre gjøre, skjønt han for sin danske Families Skyld næsten var anseet som Spion og forhadt af sin nærmeste Slægt, som han tidligere havde staaet i det inderligste Forhold til. Der paa Egnen vare flere faldne blandt Friskarernes Rœkke ved Flensborg. Her fra Egnen ere næsten alle Soldater reiste til Rendsborg, da det blev dem betydet, at Veien nordpaa var spærret ved Haderslev. En Kone fortalte igaar om hendes Hans Christian, der var saa elendig, "sølle Dreng“, fordi han skulde til Rendsborg. Han kunde ikke sove om Natten og sagde altid, „dersom han blot kunde have kommet til sin Fane“, og saaledes havde de Fleste sagt. De Gamle havde jo ogsaa sagt, at der skulde komme en gyselig, svær Krig, men vi skulde nok til Slutning komme til Kronen igjen, som vi have været altid før; men nu havde de paa Vesterdiget seet saa uhyre mange blaa Folk i Forvarsel, men det kunde jo ikke være de Danske, eftersom Tydskerne havde sagt, at de vare røde alle. Jeg trøstede Konen med, at det kunde betyde de danske Søfolk, som ogsaa ere blaa, og saa kunde hun forstaa Varslet. - Saadan er Folket i det Enkelte seet. Der vil neppe skee noget Angreb af Friserne. Jeg lod dem vide gjennem P. Marcussen, at Nordslesvigerne ikke, som det var indbildt, vilde angribe dem, men der- 
imod gjerne forbindes med dem for at værne om Slesvigs Selvstændighed, Frihed og $\mathbb{E}$ Ere, saadan som Kongen havde lovet os den. Jeg gav ham til den Ende en skriftlig Opfordring til Friserne, som han troede nok skulde virke, naar den blev rigtigen anvendt, som han nu vilde anvende den....". ${ }^{24}$ )

Medens Størstedelen af Friserne synes at have været ganske passive, frygtede Refslund og hans Folk, da Meddelelserne om Krigen mellem Danmark og Preussen naaede ud i Vestslesvig, at Indbyggerne i Leck og Niebøl skulde søge at fordrive ham. Især var Lecks Befolkning "ganske provisorisk eller republicansk, eller hvad det nu er". Selv lod Refslund dem vide, „at jeg bliver her, saalænge jeg agter at blive her uden Hensyn til alle Trusler". Alligevel forudsaa Refslund, at han eventuelt blev nødt til at trække Stafetkommandoen ind til Flensborg, da hans Vært i Medelby frygtede, at Folk vilde komme fra Leck og bryde hans Hus ned, fordi han var kendt for at være dansk. ${ }^{25}$ )

H. C. Refslund var iøvrigt allestedsnærværende i denne Tid. I „Dannevirke“ skrev han under Mærket „H“ Korrespondancer fra Krigsskuepladsen. Disse er udmærkede Kilder baade med Hensyn til Kampen ved Bov og Slaget ved Slesvig.

Efter Slaget ved Slesvig maatte Stafetlinien naturligvis trækkes tilbage. Refslund selv har aabenbart fulgt Hæren, men den 25. April trængte Folk fra Leck ind hos Kromand Baggesen i Medelby og arresterede to af Nordslesvigernes Stafetter, Chr. Lautrup fra Gestrup og Chr. Dahl og førte dem til Leck. Ogsaa Stafetternes Heste og deres personlige Ejendele tog Oprørerne med sig. I "Dannevirke“ for den 6. Maj - Bladet blev efter Tyskernes Besættelse af Nordslesvig trykt i Middelfart - giver Refslund en Redegørelse for denne afsluttende Episode i Stafettjenestens Historie og protesterer samtidig imod, at man har arresteret hans Hjælpere. Efter at have gjort Rede for de nærmere Forhold ved Stafettjenestens Oprettelse skriver han: „Jeg

24) F. A. I. J. S. 1a Prot. 17. H. A.

25) Flougs Papirer. K. B. 
paatog mig efter Krügers Opfordring at lede Stafetterne, der gik længere sydpaa og ved Mellembud ogsaa nordpaa til Jylland. Vore Beretninger, der bleve hjemsendte til den Egn, der havde udsendt os, bleve afskrevne til de enkelte Sogne. Disse vare saaledes offentlige, og mange ligge vist endnu til offentlig Eftersyn. See! dette er det Hele, og dog er denne Stafetindretning bleven behandlet som en Forbrydelse. Vi have gjort, hvad vor Egn har forlangt af os, og hjemsendt saa paalidelige Beretninger, som vi kunde, om hvad vi havde at haabe og frygte. Ligesom der i Agerskov blev besluttet, at Nordslesvigerne ikke skulde angribe nogen slesvigsk Egn, fordi den ikke deelte vore Anskuelser, saaledes have vi ogsaa stadigen virket for, hvordan det saa end skulde gaae, at bevare Fred og Enighed mellem Slesvigs forskjellige Egne, for at ikke Alt skulde ende med en slesvigsk Borger- og Bondekrig, der vilde fortære Landet. Derom skulle de Folk være Vidne, blandt hvilke vi have levet, derom skulle navnlig Beboerne i Medelby være Vidne..." Refslund hævder, at det er Krænkelse af de danske Slesvigere, at man har arresteret deres Stafetter, der saa længe de staar i Folkets Tjeneste, maa betragtes som Folkets Repræsentanter, og han slutter med at opfordre den provisoriske Regering til at frigive Stafetterne og at straffe de Folk fra Leck, som har sat dem fast.

Hvor længe Refslunds Hjælpere sad arresteret, forlyder der intet om. Selv fortsatte han sammen med Krüger sit Arbejde for at skaffe Hæren paalidelige Efterretninger om Fjendens Bevægelser, og sammen med en Række andre stedkendte Mænd gennemkrydsede de Nordslesvig og bragte Hærens Ledelse mange værdifulde Oplysninger.

Hvordan var det imidlertid gaaet den nordslesvigske Folkevæbning? Købmand Ørnstrup og Polakken Sasse instruerede Bønderne i Bevtoft, Skrydstrup, Hammelev og Moltrup Sogne i Stridsleens rette Brug. Søndag den 16. April skulde 100 Mand samles til Øvelser i Hammelev eller Skrydstrup, og der- 
efter skulde Ørnstrup og Sasse rejse til Nørrejylland for at give Bønderne Instruktion. ${ }^{20}$ )

Hvorvidt denne Øvelse er blevet afholdt, fremgaar ikke af Kilderne.

Paa dette Tidspunkt var Overledelsen af Bondevæbningerne i Nordslesvig nemlig blevet overdraget den i 1842 afskedigede Major L. E. Cirsovius, som nu havde meldt sig til Tjeneste igen, „en rigtig gammel Hugaf“, som Ploug kalder ham i et Brev til Skau. Den 9. April udnævntes han til „VæbningsInspecteur i det nordlige Slesvig“, og den 14. April sender han fra Rødding sin første Rapport til Generalmajor Hedemann.

Da han netop er ankommet, kender han kun lidt til det Materiel, som staar til hans Raadighed. Derefter skriver han: „Men efter at Stænderdeputeret Staal i Taarning Mølle har tilmeldt General-Commandoen i Colding, at i hans Valgdistrict have tegnet sig over $2000 \mathrm{Mand}$, som ønskede at blive indøvede $i$ Vaaben for at kunne forsvare Nordslesvig mod en fremrykkende Fjende, - og efter at jeg ad anden Vei er kommen til paalidelig Kundskab om, at Hr. Staal ved at skjænke ethvert Sogn i sit Valgdistrict en Dannebrogsfane, har betydeligen bidrageti en alvorsfuld rolig Retning til den endnu hos den nordslesvigske Bondestand tildeels slumrende Nationalfølelse og til at nære Ønsket om at kunne forsvare den skjønne Plet af Landet, hvorpaa de boer, tager jeg mig - i den Forudsætning, at mange blandt disse 2 a 3000 tidligere i Hs. Majestæts Tjeneste ere øvede $i$ Brugen af Vaaben - herved den Frihed at andrage paa, at en Deel Skydevaaben m. m. maatte til Afbenyttelse ved Folkevæbning i 2de District, hvor Terrainet er meget cuperet, blive tilstillet Stænderdeputeret Staal i Taarning Mølle. Og maa jeg aldeles overlade Herr Generalen Antallet af disse Vaaben med den Bemærkning, at 1. og 3. Valg-

26) Dannevirke 14. April. 
district, efter Indberetning af Assessor $\mathrm{Kjær}$ ved Rødding, stiller omtrent 7000 Mand til min Disposition..."27)

Oberst Baggesen, som modtog og videresendte Skrivelsen til Hedemann, foreslog denne, at man skulde sende $200 \mathrm{Gevæ-}$ rer til Cirsovius. Disse var nemlig ankommet til Kolding uden Angivelse af, hvorfra de stammede, og hvorhen de skulde sendes, men han formodede, at det maatte være dem, der havde tilhørt den afvæbnede Borgervæbning i Aabenraa.

Cirsovius havde aabenbart ikke megen Tillid til de saa højt berømmede Stridsleer, og samtidig med, at han i Henhold til en tidligere Henstilling fra Møller Staal beordrede de forskellige Sogne til at indsende en Fortegnelse over de Vaaben, de havde til Raadighed, anmodede han dem om at oplyse, „hvor mange Mand der $i$ ethvert Sogn findes, som tidligere $i$ Hs. Majestæts Tjeneste ere øvede i Brugen af Vaaben.“28) Det var øjensynlig hans Hensigt i Stedet for den store, slet bevæbnede og uøvede Bondevæbning at opstille et mindre Korps af geværudrustede Folk, som fra deres Soldatertid vidste, hvorledes man skulde bruge Skydevaaben. I dette blev han bestyrket ved et Brev fra Læssøe, og den 23. April skrev han til denne om at faa tilsendt en Underofficer fra Haderslev til Brug for det lille Korps, som han kunde mobilisere og sende til Hjælp til Armeen.99) Denne Henvendelse naaede imidlertid ikke at faa Betydning.

$\mathrm{Da}$ Cirsovius havde faaet Indberetning om, hvor mange Skydevaaben han kunde raade over, og hvor mange der fandtes $i$ hvert Sogn, som havde tjent i Hæren og derfor kunde betjene dem, fordelte han Geværerne til de Sogne, som var stærkest truet; „Arrild, Toftlund, Bevtoft, Skrydstrup og Gram og omliggende Sogne fik de fleste Bøsser".

Imidlertid var Rygterne om Slaget ved Slesvig allerede

27) F. A. I. J. S. 1a, Prot. 12. H. A.

28) Dannevirke 18. April.

29) F. A. I. J. S. 1a, Prot. 12. H. A. 
den 24. naaet frem til Nordslesvig - Stafettjenesten fungerede aabenbart upaaklageligt - og Krüger handlede hurtigt og energisk. Fra Bevtoft udstedte han samme Dag følgende Ordre til Bønderne: „Til Vaaben - alle Mand! Slaget staar ved Slesvig, vor Skiæbne afgjøres. Alle bevæbnede Mænd samles uopholdelig med Proviant for 2 Dage ved Arendrup og Hellevad Mølle. ${ }^{(30}$ )

Næppe havde Krüger udstedt denne Ordre, som han blandt andet ogsaa sendte til Løjtnant Siemsen i Ribe, før han fik Bud fra General Wedel om, at Styrkerne skulde møde ved Bov. Krüger lod melde tilbage, at han efter at have faaet Samling paa Styrkerne ved Hellevad vilde afgaa til Bov. ${ }^{32}$ )

Krüger sendte nu en Stafet med sit Opraab til Cirsovius, som just var i Færd med at inspicere Styrken i Skodborg; Majoren begav sig ufortøvet til Rødding, og her modtog han en Ordre fra Oberstløjtnant Baggesen ved Generalkommandoen i Kolding om, at han straks skulde træffe de Foranstaltninger, der stod i hans Magt „for at kunne møde en maaske nordefter fremtrængende deboucherende fjendtlig Styrke. ${ }^{\text {(33) }}$

Samtidig med denne Ordre fik imidlertid Cirsovius en Skrivelse fra Krigsminister Tscherning, og den tog helt Modet fra ham. Tscherning havde hørt om Cirsovius paabegyndte „Bevæbningsværk“, og han anmodede $\mathrm{i}$ den Anledning Majoren om at gøre sig bekendt „med den af mig givne Instrux for de Officerer, som ere fordeelte $i$ Districterne $i$ den Hensigt at organisere Folkevcebningen." Tscherning understregede i Forbindelse hermed, at det vilde være umuligt at forsvare et Land mod en regulær Hær ved Hjælp af "Partielvæbninger". De kunde mulivis bruges mod en fremrykkende Hærs Fortrop eller mod omstrejfende Bander, men ikke mod en hel Armé. De maa operere sammen med Hæren, og de bør helst slutte

30) Krigsministeriets Arkiv I, til Prot. IV. 1848, Løbenr. 31 R. A.

s2) F. A. I. J. S. 1a, Prot. 17. H. A.

ss) Krigsmin. Arkiv I, til Prot. IV, 1848, Løbenr. 31 R. A. 
sig til Hæren. Tscherning slutter: „Nu derimod, netop i denne Tid, maa man ikke uden yderlig Nødvendighed eller øiensynlig og tilsvarende Nytte drage Landsmænd fra Huus og Jord, og lade vi dem avanture sig for meget ud over Forbindelse med Hæren, saa udsætte vi dem og deres Egn for meget for en streng Hjemsøgelse af den fremrykkende Fjende. Vi tør ikke hengive os til det Haab at kunne forsvare en straatægt Landsby som et andet Sarragossa. ${ }^{\text {"s4 }}$ )

Skønt Skrivelsen ikke tager Sigte paa den konkrete Situation, i hvilken Cirsovius befandt sig - Brevet er jo skrevet for Slaget ved Slesvig - og kun omhandler de Foranstaltninger, Cirsovius allerede før havde truffet, følte denne sig i en meget vanskelig Situation, idet han opfattede Skrivelsen saaledes, at han ikke med sine Styrker burde søge at løse militære Opgaver. Paa den anden Side havde han dog de udtrykkelige Ordrer fra General Wedel og Oberstløjtnant Baggesen. Han besluttede sig da til at undlade at sammenkalde de Styrker, han havde Forbindelse med, og i Stedet ride alene til Hellevad Mølle for at afblæse Ekspeditionen. Selve Tschernings mere velmente end just klare Skrivelse er et blandt flere Eksempler paa det uheldige $i$, at han ikke nøjedes med sit Embede som Krigsminister, men ogsaa blandede sig i Forholdene paa selve Krigsskuepladsen.

I Hellevad mødte imidlertid adskillige spredte Styrker. Løjtnant Siemsen, som havde modtaget Krügers Efterretning Kl. $3^{1 / 2}$ om Eftermiddagen den 24. April og General Wedels Ordre en halv Time senere, kunde allerede Kl. 6 forlade Ribe med 55 frivillige, hver med 60 skarpe Patroner. Kl. 3 næste Morgen stod han i Hellevad. ${ }^{35}$ ) Foruden Ribe Borgerne modte ogsaa frivillige fra Skærbæk med flere Byer under Kommando af Assessor Aarøe samt en Del af Krügers Folk med denne selv i Spidsen. ${ }^{36}$ )
34) ibid.
35) ibid.
36) Ribe Stifts Avis 27. April. 
Endelig var nærmest ved et Tilfælde den senere kendte Kaptajn og Højrepolitiker Jagd kommet til Stede. Han var rejst til Nordslesvig for at melde sig til Tjeneste, hvor der var Brug for ham. Den 24. April mødte han paa Landevejen mellem Sommersted og Haderslev Peter Skau, som kom galopperende paa en skumbedækket Hest; han raabte til Jagd, at Preusserne havde sejret og var paa Vej nordpaa. Overalt mærkede Jagd en almindelig Modløshed, og han mødte flere kendte Nordslesvigere, der var paa Flugt til Kongeriget. Selv blev han imidlertid indhentet af en Stafet fra Krüger, der stævnede ham til Bevtoft. Her fik Jagd Ordre til at ile til Hellevad. Han fortæller selv om denne Rejse:

„Ved Solnedgang passerede jeg det højtliggende Strøg af Egnen ved Toftlund Kirke, hvorfra man har en vid Udsigt til alle de fjærnere og nærmere liggende Landsbyer, og der saa jeg et Syn, der i min daværende Stemning gjorde et saa overraskende og gribende Indtryk paa mig, at jeg næsten overvældedes af Bevægelse. Fra de fleste af Byerne saa jeg en lille Flok af bevæbnede Mænd med en lille Dannebrogsfane i Spidsen drage mod Syd; - den synkende Aftensol kastede hist og her et Blink paa Bajonetterne, indtil de smaa Hobe efterhaanden forsvandt paa den udstrakte Hede under den tiltagende Aftenskumring. Da jeg naaede Agerskov var det allerede temmelig mørkt; men et Lysskær paa Kirkegaarden vakte min Opmærksomhed, og jeg fandt der en Hob kraftige, unge Mænd staaende omkring en Jerngryde, der hang over et flammende Baal. Oppe paa Kirketaget sad en rask Karl og brød Blypladerne løs, hvorefter disse kastedes ned i Gryden, hvorfra det smeltede Bly hurtigt hældtes i de fra alle Sider fremstrakte Gryder, og efter at hver Mand havde faaet sit bestemte Antal Kugler, stillede de alle uden for Kirkegaarden og marcherede ligeledes mod Syd".

Paa Mødestedet var allerede mange samlede. Jagd fortæl- 
ler, at der endog var en Flok forvovne Nordfrisere, der var opJagt til at slaas, men iøvrigt særdeles udisciplinerede. Jagd benyttede Natten til at eksercere lidt med en Del af de mødte. ${ }^{37}$ )

Den 25. om Eftermiddagen kom Major Cirsovius, som gjorde de frivillige bekendt med den Ordre, han havde modtaget fra Krigsministeren. Ifølge Siemsens Beretning lød denne paa, at de frivillige Korps ikke skulde operere i Forbindelse med Armeen, men forblive i deres Hjemstavn indtil videre. Dette staar jo iøvrigt slet ikke i Tschernings Skrivelse, hvor dog maaske det sidste Stykke kan fortolkes i den Retning, og man maa formode, at Cirsovius slet ikke har vist Krüger og Siemsen selve Ordren, men kun refereret den.

Krüger sendte straks sine Folk hjem, mens Siemsen besluttede sig til at vente til næste Dags Morgen, idet han haabede, at General Wedel kunde have en senere Ordre fra Krigsministeriet, ifølge hvilken det kunde tillades de frivillige at operere i Forbindelse med Hæren. Om Aftenen fik han da Melding fra Wedel om, at han ventede at indtræffe i Hellevad den 26. om Formiddagen. Da Generalen og hans Styrker imidhertid ikke indtraf til den aftalte Tid, vendte Løjtnant Siemsen tilbage til Ribe. ${ }^{38}$ )

Jagd havde imidlertid ikke Lyst til at rejse hjem, og det var der andre, der heller ikke havde. Om Natten boede han paa en nærliggende Gaard, og her blev han vækket af to Mænd, der Dagen før var blevet udnævnt til „Korporaler“. De kom som Udsendinge fra henved 100 af de mødte for at spørge ham, om han kunde tænke sig at være deres Leder i Krigen. Det paatog Jagd sig hellere end gerne, og med disse som Kærnen dannede han "Det nordslesvigske Frikorps", der straks sluttede sig til General Wedels Tropper. Det var en Samling forvovne Karle med Eventyrlyst i sig, men de "gule Kanarie-

37) Chr. Jagd: Det nordslesvigske Frikorps. »Dannebrog « II, 1881.

38) Krigsmin. Arkiv I, til Prot. IV, Løbenr. 31 R. A. 
fugle“, som de kaldtes, kom til at gøre god Nytte i Forposttjenesten..$^{30}$ )

Cirsovius synes at have været ivrigere for at undskylde sine Dispositioner over for Krigsministeren end over for Generalkommandoen. Han gør rede for, at hans Hensigt aldrig har været anden end "at Aftenstund og ledige Timer" skulde anvendes af de gamle Soldater til at indøve Ladning og Fyring mod eventuelle Friskarer og at ove dem med Pikerne $i$ at afværge Bajonetstød, og han har netop søgt at inspicere Styrkerne paa Tider, hvor det ikke kunde berøve Gaardene den nødvendige Arbejdskraft. Han beklager, at det viste sig umuligt for ham at hindre Bønderne $i$ at samles i Hellevad, men denne „udisciplinerede med Geværer, Leer, Piker etc.“ udrustede Folkemasse formaaede han ikke at styre. ${ }^{40}$ )

Skrivelsen viser med al onskelig Tydelighed, at Cirsovius overhovedet ikke har formaaet at sætte sig i Respekt; men da Krüger gav Bønderne Ordre til at vende hjem, lystrede de.

Den nordslesvigske Folkevæbning kom saaledes aldrig til at træde i Funktion, og over for de velorganiserede fjendtlige Styrker, som nu rykkede op i Nordslesvig, havde den naturligvis ikke haft større Chance for at kunne gøre Modstand end Bønderne Aaret efter ved Brøns. At den dog muligvis under selve Tilbagetoget kunde have været til Nytte, tyder jo Ordrerne fra Wedel og Baggesen paa, og det har sikkert været en dyb Skuffelse for Nordslesvigerne, at de maatte vende hjem med uforrettet Sag; men deres Danskhed havde de vist og Viljen til at forsvare den.

Da Tyskerne besatte Nordslesvig, opslog Oberst Jenssen-Tusch sit Hovedkvarter som "Kommandant" i Ørderup, og til ham maatte nu Omegnens Sognefogder aflevere de Vaaben, Befolkningen laa inde med. Undlod de dette, og blev Vaabnene fundet ved en Husundersøgelse, vilde de blive behandlet som Krigs-

3a) "Dannebrog « II, 1881.

10) Krigsmin. Arkiv I, til Prot. IV, Løbenr. 31. R. A. 
fanger. Alene Sognefoged Thomas Høyer i Agerskov maatte aflevere 68 „Piker“, 60 Bøsser, 4 Sabler og 2 Pistoler, og det har sikkert ikke gjort hans Bitterhed mindre, at den Oprørsofficer, han stod overfor, var Fader til den raske unge Løjtnant, som havde organiseret Folkevæbningen i dens første Dage. ${ }^{41}$ )

41) Nordslesvigsk Søndagsblad Nr. 7. 1899. 